\title{
Late Holocene hydrology of Lake Maharlou, southwest Iran, inferred from high-resolution sedimentological and geochemical analyses
}

\author{
Elodie Brisset $(\mathbb{D} \cdot$ Morteza Djamali • Edouard Bard • Daniel Borschneck • \\ Emmanuel Gandouin • Marta Garcia • Lora Stevens • Kazuyo Tachikawa
}

Received: 13 September 2017/ Accepted: 21 August 2018

(C) Springer Nature B.V. 2018

\begin{abstract}
Sedimentological (dry density, micro-facies analysis on thin-slides, X-ray diffraction, layer counting) and elemental analyses (X-ray fluorescence) of a 3.5-m-long sediment core (MAH-B) from saline Lake Maharlou (SW Iran) were used to infer hydrological changes over the last $\sim 3800$ years. The sediment consists of thin, alternating beds of evaporites (halite, gypsum), carbonates (calcite, aragonite) and detrital minerals (quartz, muscovite, chlorite). We interpret the data with respect to three main hydrologic conditions: (1) nearly complete desiccation of the lake, marked by frequent halite layers, (2) hypersaline conditions marked by gypsum abundance, (3) wet
\end{abstract}

E. Brisset $(\bowtie) \cdot$ M. Djamali · E. Gandouin

CNRS, IRD, UMR 7263 IMBE, Univ Avignon, Aix

Marseille Univ, Aix-en-Provence, France

e-mail: elodie.brisset@gmail.com

E. Brisset

IPHES, Zona Educacional 4, Campus Sescelades URV, Edifici W3, Tarragona, Spain

\section{E. Brisset}

Àrea de Prehistòria, Universitat Rovira i Virgili (URV), Avinguda de Catalunya 35, Tarragona, Spain

E. Bard · D. Borschneck · M. Garcia $\cdot$ K. Tachikawa CNRS, IRD, Coll France, CEREGE, Aix Marseille Univ, Aix-en-Provence, France

L. Stevens

Department of Geological Sciences, California State

University, Long Beach, USA conditions, characterized by high river-borne terrigenous sediment input with high potassium content. Distinct flood layers indicate fluvial activity. From about 3800-2000 cal year BP, terrigenous sediment supply was high, with peaks at 3700-3650, 3500-3450, and 3400-3250 cal year BP. Evaporative conditions were not common. From ca. 2000 cal year BP to present, detrital minerals are less abundant, and the increase in gypsum abundance suggests drier climate with enhanced evaporation. Frequent desiccation events occurred from 1100 to 700 cal year BP. The late Holocene hydrology of Lake Maharlou corresponds well with records of dune formation and phases of river alluviation in Iran and the Arabian Peninsula, and with regional speleothem records. In addition to the influence of climate change on the lake hydrology, ancient humans modified water drainage in the catchment. Periods of subterranean tunnel (qanats) use correspond to dramatic shrinkage of the water body. We propose that climate changes drove longterm water shortages that were enhanced by anthropogenic activities, leading to more frequent desiccation of the lake during the last millennium.

Keywords Paleohydrology $\cdot$ Saline lake · Evaporite · Detrital supply · Drought · Human disturbance 


\section{Introduction}

Arid and semi-arid regions, which cover one quarter of the continental Earth surface, are particularly vulnerable to droughts because of the scarcity of water resources. In Iran, especially in the southeast and southwest regions, the severity of drought has increased during the last 30 years (Bari Abarghouei et al. 2011). Climate models predict that Iran's wet regions will receive more rainfall, while its dry regions will be generally drier, continuing this trend of protracted droughts (Abbaspour et al. 2009). Droughts superimposed on the overall drying have significant economic and environmental consequences. The severe drought in AD 1999-2000 resulted in a 30\% loss of productivity in the agricultural sector of Iran compared with previous years (Salami et al. 2009) and also badly affected livestock, fisheries, and forestry. The combination of drought, the rising demand for water for irrigation and domestic use and poor water management have critically affected all water resources of the country (Motagh et al. 2008).

During the last decade, numerous lakes of the semiarid Iranian plateau (Urmia, Hamoun, Parishan, Maharlou) have reached critical water levels. Lake Urmia, one of most emblematic lakes in the Near East because of its large size, lost $70 \%$ of its surface area between 2002 and 2014, despite its environmentally protected status (Wurtsbaugh et al. 2017). The disappearance of lakes in several regions of Iran reveals the serious problem of long-term sustainability of surface water resources in the region, but also highlights the depleted state of the ground-water resources. The main cause of the recent drop in lake levels is anthropogenic alteration of the water system (Tourian et al. 2015), including dam construction, channel deviation, and groundwater pumping, all of which result in a water deficit.

Paleolimnological studies allow to better understand changes in a lake's hydrological regime over long timescales (Dearing 2013), providing boundary conditions that help establish sustainable management strategies of water resources (Coops et al. 2003). In arid and semi-arid regions of Iran, sediment archives from hydrologically closed lakes have demonstrated their high potential for deciphering paleohydrological changes (Stevens et al. 2012; Jones et al. 2015; Aubert et al. 2017) through a range of biotic and abiotic indicators (ostracods, diatoms, chironomids, oxygen isotopes of endogenic carbonates). Fewer investigations have reconstructed lake paleohydrology in Iran with sedimentology and major element geochemistry, with the exception of Lake Urmia (Kelts and Shahrabi 1986) and the recent studies on Lake Neor (Sharifi et al. 2015). These proxies may provide valuable highresolution data from which lake desiccation and fluvial activity can be reconstructed (Neugebauer et al. 2016). In this study, we present new high-resolution sedimentological (dry bulk density, micro-facies analysis, $\mathrm{X}$-ray diffraction) and major element (X-ray fluorescence) analyses of MAH-B, a 3.5-m-long sediment core, to investigate centennial-scale variations in the hydrology of Lake Maharlou for the last 3800 years.

\section{Site description}

Lake Maharlou is located $10 \mathrm{~km}$ southeast of the city of Shiraz $\left(29^{\circ} 29^{\prime} \mathrm{N}, 52^{\circ} 45^{\prime} \mathrm{E}\right)$, in an intermontane depression of the Zagros Fold-Thrust Belt. The lake, with an elevation of $1460 \mathrm{~m}$ a.s.1., lies in a vast, $3928-\mathrm{km}^{2}$ endorheic watershed surrounded by mountains that reach $2800 \mathrm{~m}$ a.s.l. Basement rocks mainly consist of Mesozoic/Cretaceous limestone-dolomites and marls. Several evaporitic outcrops, including gypsum, anhydrite, and halite beds, are exposed in the eastern part of the lake (Faghih et al. 2012; Fig. 1).

Iranian climate is characterised by hot and dry summers associated with northerly winds (i.e. Shamal) from the Mediterranean high to South Asian monsoon low (Tyrlis et al. 2013). Persistence of this synoptic pattern produces great dust storms along the Persian Gulf that do not affect the southern continental slope of the Zagros (Nabavi et al. 2016). Winters are dominated by cold dry air from the Siberian high. Penetration of the most intense depressions from the Atlantic and Mediterranean triggers winter and spring precipitation (Alijani and Harman 1985), especially in the Zagros massif where snow is deposited at high altitude.

Lake Maharlou was a nearly permanent lake in the recent past, but since its near desiccation during summer 2002, seasonal drying of the lake has become a common phenomenon (Dumas et al. 2003; Fayazi et al. 2007). Today, the depth of the lake varies seasonally from a completely dried surface in summer months to about $3.5 \mathrm{~m}$ in early spring. The depth of the basin is greater to the northwest (Fig. 1). The area of the lake at a high stand of $3.5 \mathrm{~m}$ depth is $275 \mathrm{~km}^{2}$ 


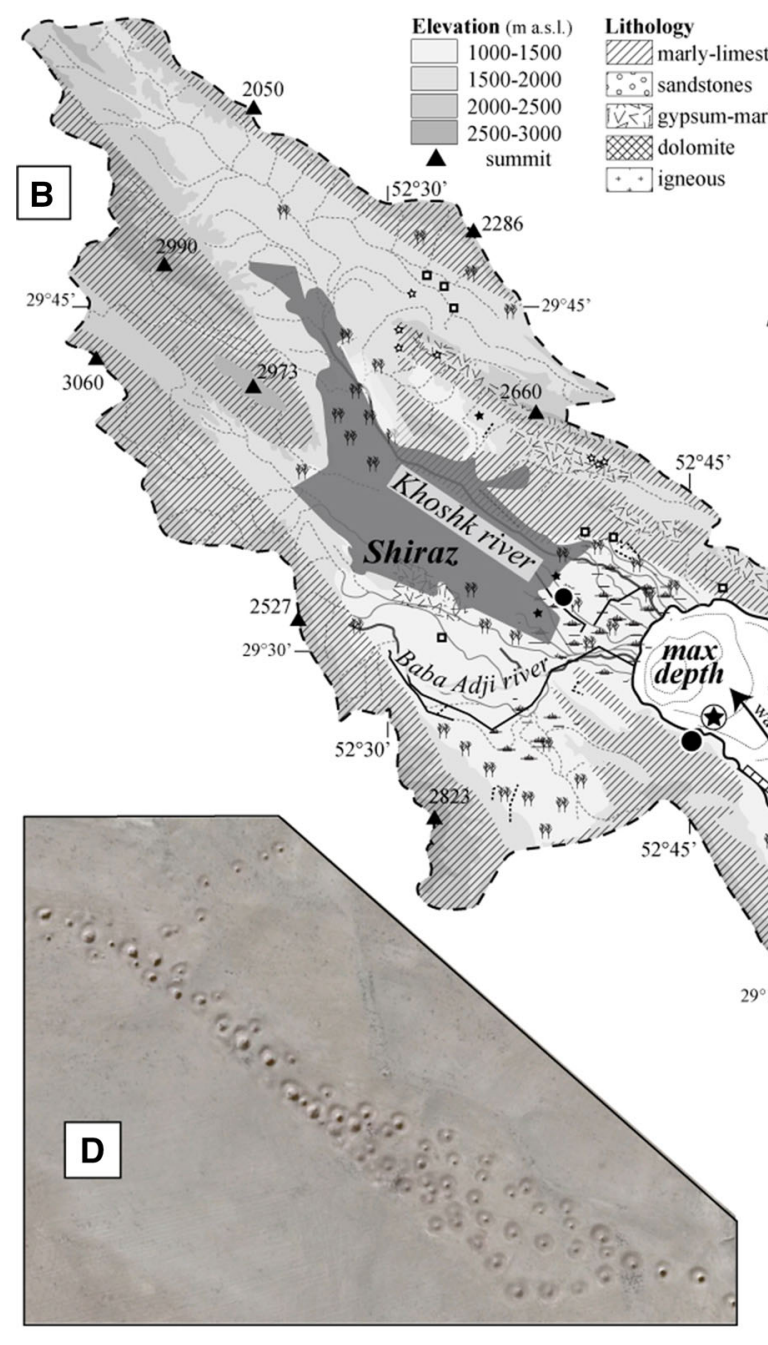

Fig. 1 a Spatial distribution of annual precipitation in Iran and location of the study site near the city of Shiraz (white star). b Map of the Lake Maharlou watershed, including topography, geology, hydrology, and anthropogenic features. Note that map details differ between the northern and southern part of the watershed because several sources of information were integrated. The black star indicates the MAH-B coring location. The two black dots indicate the location of the surface sediment

(Dumas et al. 2003). A detailed hydrologic study of the lake based on instrumental measurements from 1988 to 1992 and hydroclimate data provided by the Karstic Research Center of Teheran showed that inputs to the lake originate from catchment runoff $(85 \%)$ and karstic springs $(15 \%)$ that feed two rivers, Khoshk and Baba Adji (specific discharge of 3.59 and $1.85 \mathrm{~L} /$ $\mathrm{s} / \mathrm{km}^{2}$, respectively). These rivers form a delta in the northern part of the lake (Dumas et al. 2003). Karstic losses, a common phenomenon in Zagros (Rezaei et al.

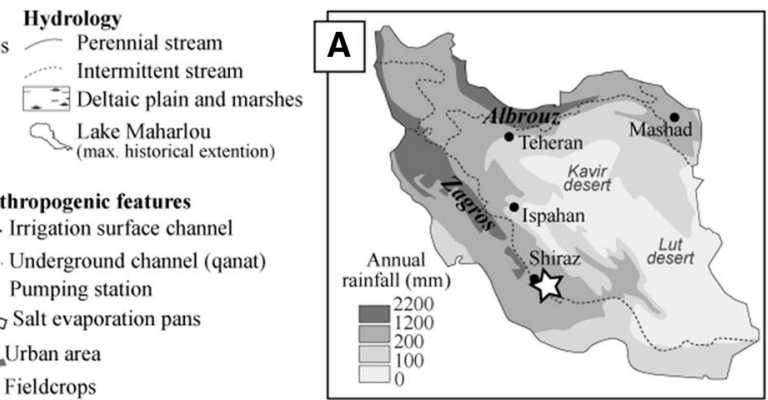

w Fieldcrops

is Sheepfold

$\checkmark$ Ruins

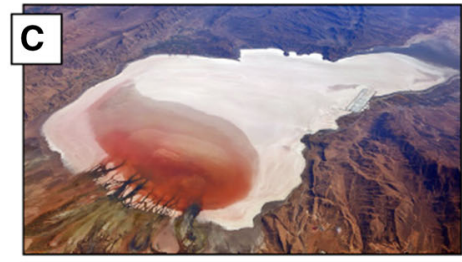

les. c Aerial photograph of Lake Maharlou during the phase of nearly complete drying, with the view toward the southeast. Spatial extension of the halite crust is visible in white and hypersaline lake waters in red. d Satellite image (Google Earth) of the southeastern part of the watershed (location in b), representing several generations of regular holes of a qanat irrigation system. (Color figure online)

2013), are considered negligible since the basin floor is covered by a thick impermeable clay deposit. Precipitation is seasonal, occurring mainly from January to April. Annual mean precipitation is estimated at $350 \mathrm{~mm} /$ year (Shiraz station). During the monthlyinstrumented period of 1988, the negative balance between precipitation and evaporation was compensated for by karstic inputs, preventing complete drying of the lake (Dumas et al. 2003). Altogether, the hydrological regime of Lake Maharlou is driven by 
karstic resurgence throughout the year, winter/spring rainfall, and summer evaporation. The watershed of Lake Maharlou is also occupied by a dense network of surface and underground tunnels (qanats) and small water pools that are partially abandoned today (Fig. 1b). These infrastructures, essentially located in foothills, provide a freshwater supply for agriculture and pastoral activities on the plain.

\section{Materials and methods}

Four contiguous drives (MAH-B-D1, D2, D3 and D4), each $1 \mathrm{~m}$ in length, were taken with a Russian Corer in the southwest quadrant of the northwestern depression of Lake Maharlou $\left(29^{\circ} 27^{\prime} 40.5^{\prime \prime} \mathrm{N} ; 52^{\circ} 43^{\prime} 45.6^{\prime \prime} \mathrm{E}\right)$ in September 2012. Main sedimentary facies were described using macroscopic visual features (colour, texture and structure, presence of macrofossils). The result is a master core, $355 \mathrm{~cm}$ in length, designated MAH-B.

Seven samples were radiocarbon dated at the Poznan Radiocarbon Laboratory. To avoid contamination by fossil organic carbon and the 'hard-water effect,' only botanical macroremains and charcoals were dated. Because of the paucity of terrestrial macroremains, sediment samples were wet sieved at $100 \mu \mathrm{m}$, avoiding the use of alcohol. Terrestrial organic particles were then picked one by one under a binocular microscope. Humic acid removal pretreatment (Poznan Radiocarbon Laboratory) was skipped because of the small weight of the sample for preparation of graphite. The age-depth model was developed using a smooth spline (type 4 argument) in the Clam R package (Blaauw 2010), based on probability distributions of the ${ }^{14} \mathrm{C}$ ages, and the IntCal13 calibration curve (Reimer et al. 2013). Ten thousand iterations were run to calculate the best age probability and $2 \sigma$ envelope. Salt layers that represent rapid sedimentation were considered instantaneous deposits and were excluded from the age-depth model.

Two sediment segments $(110 \mathrm{~mm} \times 20 \mathrm{~mm})$ were sampled for thin sections at $110-120 \mathrm{~cm}$ and 279-291 cm. The segments were freeze-dried and impregnated with epoxy resin (MK Factory) under vacuum following the procedure of Brauer and Casanova (2001). Polished slides were observed under a compound microscope at $10 \times, 50 \times$, and $100 \times$ magnification (IMBE laboratory). XRF elemental analysis was performed on a 1-m-long U-Channel with an ITRAX $^{\mathrm{TM}}$ core scanner (Cox Analytical Systems) at the CEREGE laboratory. High-resolution visual scans were acquired with an optical camera before covering the sediment with polyethylene foil to prevent drying during analysis. The radiographic scan was done at $200-\mu \mathrm{m}$ increments with parameters fixed at $45 \mathrm{kV}$, $40 \mathrm{~mA}$ and a dwell time of $700 \mathrm{~ms}$. The relative abundances of $\mathrm{Si}, \mathrm{K}, \mathrm{Fe}, \mathrm{Ti}, \mathrm{Ca}, \mathrm{S}, \mathrm{Sr}, \mathrm{Cl}$ were measured by X-ray excitation using a Mo-source tube set at $30 \mathrm{kV}$ and $45 \mathrm{~mA}$ for $15 \mathrm{~s}$, at a step of $500 \mu \mathrm{m}$. Significant changes in the geochemical composition were defined by cluster analysis, both stratigraphically constrained and unconstrained, using the CONISS algorithm of the Rioja R package (Juggins 2012). The number of significant zones was defined by comparison to the Broken-stick model (Bennett 1996). A visual layer counting was done with the support of a high-resolution optical scan, a radiographic scan, and XRF element variations. The minimal resolution of layer counting was $1 \mathrm{~mm}$.

Contiguous sub-samples, 2-cm thick, were collected on the remaining core. Seventy samples of a constant volume of $7 \mathrm{~cm}^{3}$ were taken at approximately 10 -cm intervals, dried at $60{ }^{\circ} \mathrm{C}$ for $48 \mathrm{~h}$, weighed to calculate dry bulk density, and then crushed using an agate mortar. Additionally, two surface sediment samples, one from the Khoshk riverbed, and one from soil on the west bank of the lake near the coring site (Fig. 1), were analysed to characterize detrital mineral species of the watershed. Mineral composition of 20 bulk samples was characterised by X-ray diffraction on powder deposited on zero-background silicon plates (CEREGE laboratory) with a PANalytical $X$ 'Pert Pro diffractometer. To verify that drying temperature did not modify mineralogical species, one air-dried sample $\left(<25^{\circ} \mathrm{C}\right)$ was measured. Samples were scanned from $5^{\circ}$ to $70^{\circ}(2 \theta)$, with an increment step of $0.033^{\circ}$ and an acquisition time per sample of $3 \mathrm{~h}$. The X-ray emission source, cobalt $(\lambda=1.79 \AA)$, was set at $40 \mathrm{kV}$ and $40 \mathrm{~mA}$. Peak identification was performed using the automated peak-match software X'Pert High Score Plus (Degen et al. 2014). 


\section{Results}

Chronology

Of the seven AMS ${ }^{14} \mathrm{C}$ ages (Table 1), six were used to create the chronological model. Given its very low carbon weight (0.03 $\mathrm{mg} \mathrm{C})$, Poz-83775 $(269 \mathrm{~cm})$ was very close to the detection limit of the instrument and was rejected. The remaining ages are stratigraphically coherent if either sample Poz-83773 or Poz-81500 is excluded (Fig. 2). These two samples have low but equivalent weights of carbon ( $0.1 \mathrm{mg} \mathrm{C})$. Poz-83773 comprises a mixture of numerous half-mm-long particles of charcoal, seeds, and insects, whereas Poz-81500 consists solely of charcoal $(\sim 3 \mathrm{~mm}$ long). The most common cause of age bias in dating terrestrial material from lake sediment is long-term retention in the lake catchment. It is more likely that Poz-83773 was reworked than that Poz-81500 was rejuvenated. Sample Poz-83775 was accepted a posteriori because the $2 \sigma$ calibration range fits the model uncertainty. Thus, the final age-depth model is based on six ${ }^{14} \mathrm{C}$ dates. The age-depth model (Fig. 2) indicates that MAH-B spans the last $3800 \pm 370$ years, with an average $2 \sigma$ uncertainty of 250 years. The highest sedimentation rates occurred from 3700 to 3250 cal year BP (mean $=1.5$ $\mathrm{mm} /$ year). The sedimentation rate was lowest (0.5 mm/year) between 3250 and $1000 \mathrm{cal}$ year BP, increased from 2000 to 400 cal year BP $(1.1 \mathrm{~mm} /$ year), and decreased again from $400 \mathrm{cal}$ year BP to Present $(0.4 \mathrm{~mm} /$ year$)$.

\section{Bulk sediment composition}

MAH-B is composed of very thinly bedded (1-2-cm thick) to laminated $(0.1-1 \mathrm{~cm})$ sediments that display an alternation of sand-size crystals and beige to light brown, silt-clay layers (Fig. 3). Contacts between beds are generally sharp, mainly because of the abrupt changes in particle size. The dry bulk density varies between 1.2 and $2.0 \mathrm{~g} / \mathrm{cm}^{3}$. The upper $30 \mathrm{~cm}$ of the core is exclusively halite, reflecting the presence of the decimetre-thick salt crust encountered during coring. XRD measurements indicate the presence of both chemical and clastic components in all 19 samples. The comparison between the samples dried at different temperatures $\left(25^{\circ} \mathrm{C}\right.$ vs $\left.60{ }^{\circ} \mathrm{C}\right)$ indicates that sample desiccation induced a partial dehydration of gypsum to bassanite. Thus, the presence of bassanite is a preparation artifact and is considered to have been gypsum. Ranking minerals from the most dominant to least, the sediment consists of a constant presence of gypsum $\left(\mathrm{CaSO}_{4} \cdot 2 \mathrm{H}_{2} \mathrm{O}\right)$, halite $(\mathrm{NaCl})$, strontium in aragonite $\left(\mathrm{CaCO}_{3}-\mathrm{Sr}\right)$, calcite $\left(\mathrm{CaCO}_{3}\right)$, quartz $\left(\mathrm{SiO}_{2}\right)$, muscovite $\left(\mathrm{KAl}_{2}(\mathrm{Si}, \mathrm{Al}) \mathrm{O}_{10}(\mathrm{OH})_{2}\right)$ and chlorite $\left((\mathrm{Mg}, \mathrm{Fe})_{3}(\mathrm{Si}, \mathrm{Al})_{4} \mathrm{O}_{10}\right)$. Dolomite $\left(\mathrm{CaMg}\left(\mathrm{CO}_{3}\right)_{2}\right)$ and celestine $\left(\mathrm{SrSO}_{4}\right)$ occur regularly, but XRD peak heights are lower. Occurrences of pyrite $\left(\mathrm{FeS}_{2}\right)$ at 92 and $337 \mathrm{~cm}$, glauberite $\left(\mathrm{Na}_{2} \mathrm{Ca}\left(\mathrm{SO}_{4}\right)_{2}\right)$ at $32 \mathrm{~cm}$, and

Table 1 Radiocarbon ages obtained on core MAH-B

\begin{tabular}{|c|c|c|c|c|c|c|c|}
\hline $\begin{array}{l}\text { Core } \\
\text { section }\end{array}$ & $\begin{array}{l}\text { Core section } \\
\text { depth }(\mathrm{cm})\end{array}$ & $\begin{array}{l}\text { Master core } \\
\text { depth }(\mathrm{cm})\end{array}$ & Material & $\begin{array}{l}\text { Laboratory } \\
\text { code }\end{array}$ & Age ${ }^{14} \mathrm{C} B P$ & $\begin{array}{l}\text { Age cal year BP } \\
( \pm 2 \sigma)\end{array}$ & $\begin{array}{l}\text { Weight } \\
(\mathrm{mg} \mathrm{C})\end{array}$ \\
\hline D1 & 43 & 43 & $\begin{array}{l}\text { Charcoals, } \\
\text { Coleoptera, seed }\end{array}$ & Poz-81502 & $390 \pm 30 \mathrm{BP}$ & $320-509$ & 0.2 \\
\hline D1 & 88 & 88 & Plant fragment & Poz-81501 & $655 \pm 35 \mathrm{BP}$ & $556-673$ & 0.15 \\
\hline D2 & $62-70$ & 159 & $\begin{array}{l}\text { Charcoals, } \\
\text { Coleoptera, seed }\end{array}$ & Poz-83773 & $2450 \pm 50 \mathrm{BP}$ & $2359-2707$ & 0.12 \\
\hline D3 & 14 & 193 & Charcoal & Poz-81500 & $1950 \pm 50 \mathrm{BP}$ & 1741-2002 & 0.1 \\
\hline D3 & $58-66$ & 237 & $\begin{array}{l}\text { Charcoals, } \\
\text { Coleoptera }\end{array}$ & Poz-83774 & $2820 \pm 90 \mathrm{BP}$ & $2762-3162$ & 0.07 \\
\hline D3 & $90-96$ & 269 & $\begin{array}{l}\text { Charcoals, } \\
\text { Coleoptera, seed }\end{array}$ & Poz-83775 & $3800 \pm 180 \mathrm{BP}$ & $3717-4803$ & 0.03 \\
\hline D4 & $66-74$ & 321 & $\begin{array}{l}\text { Charcoals, } \\
\text { Coleoptera, seed }\end{array}$ & Poz-83776 & $3370 \pm 35 \mathrm{BP}$ & $3496-3697$ & 0.16 \\
\hline
\end{tabular}

The rejected age is in italics 
Fig. 2 Age-depth model for core MAH-B and lithostratigraphy and sedimentation rate. The AMS ${ }^{14} \mathrm{C}$ ages are represented by their probability density functions. The age rejected before modeling is crossed in red. The model calculated with 10,000 iterations is given in the grey scale (higher probability is darker), and the best model is shown as a green line. Grey horizontal band illustrates a layer interpreted as non-continuous sedimentation (coarse crystal beds), which were "removed" before age modeling

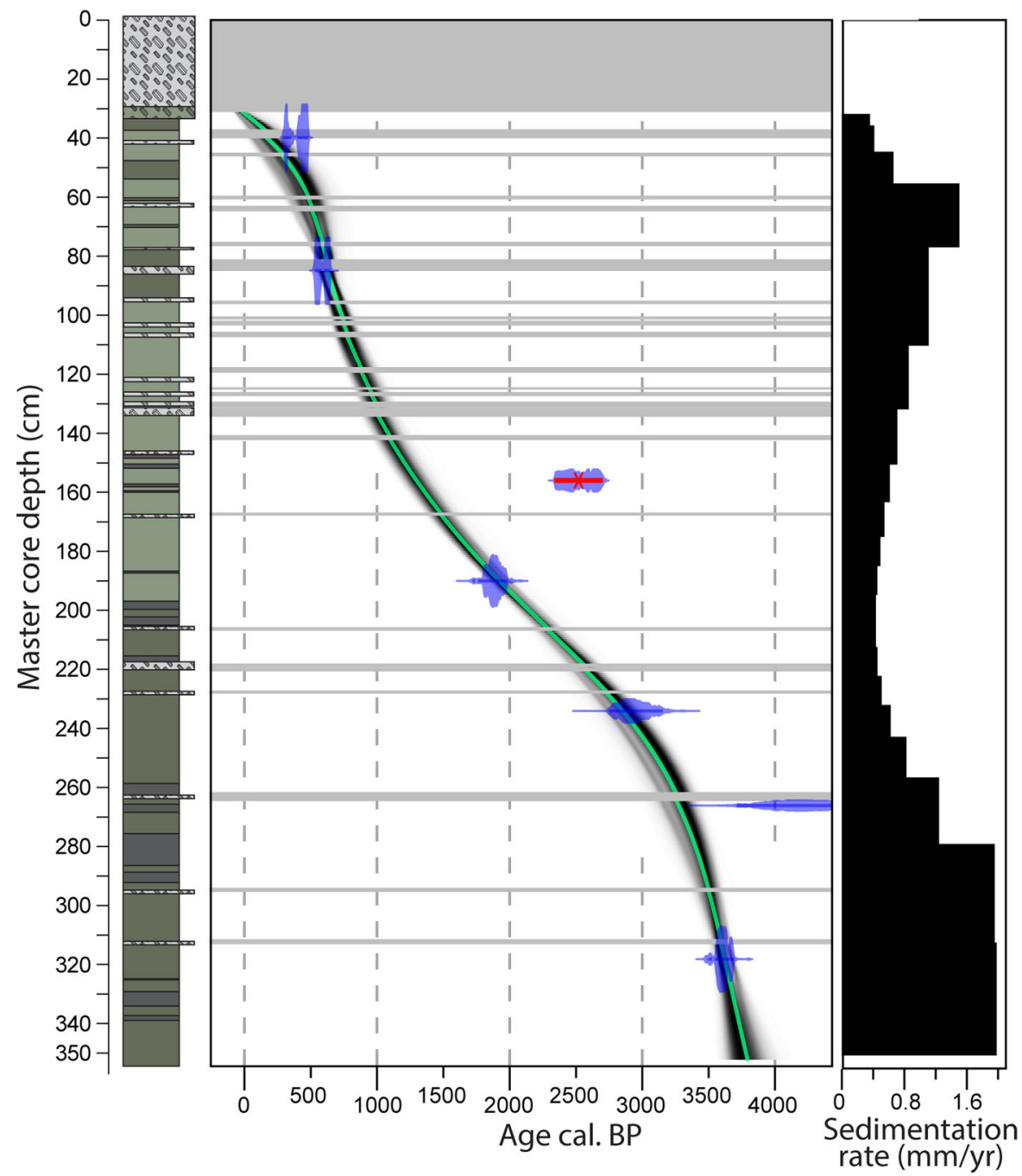

palygorskite $\left((\mathrm{Mg}, \mathrm{Al})_{2} \mathrm{Si}_{4} \mathrm{O}_{10}(\mathrm{OH}) \cdot 4\left(\mathrm{H}_{2} \mathrm{O}\right)\right)$ at 159 , 281 and $349 \mathrm{~cm}$ were also noted. Mineralogical analysis of the surface sediment from the west bank of the lake near the coring site, as well as the sample from the Khoshk riverbed, the main tributary river of Lake Maharlou (Fig. 1), showed a similar composition of mostly quartz and calcite, with minor amounts of dolomite.

\section{Lithofacies}

Microscopic examination of thin sections and sieved fractions greater than $100 \mu \mathrm{m}$ provided qualitative information on sediment texture and constituents, enabling the designation of three lithofacies (Table 2).
Coarse Crystal Beds (CCB) are characterised by the nearly exclusive presence of euhedral $\mathrm{mm}$-size halite crystals free of finer matrix (Fig. 4b). CCBs are represented in dark grey on the radiograph (Fig. 4a). Beige to grey Silt-Clay Beds (SCB) consist of nongraded silt particles of mainly palisade gypsum crystals (g1 in Fig. 4c), rounded gypsum crystal (g2 in Fig. 4c) and aragonite (Fig. 4d) with some halite crystals in association with a finer matrix of calcite (Fig. 4e) and clay. Dark SCB (D-SCB) are richer in clay compared to lighter SCB (L-SCB). These beds are represented in medium grey in radiographic images (Fig. 4a). Homogeneous Clay Beds (HCB) consist of non-graded fine-silt to clay with scattered amorphous 


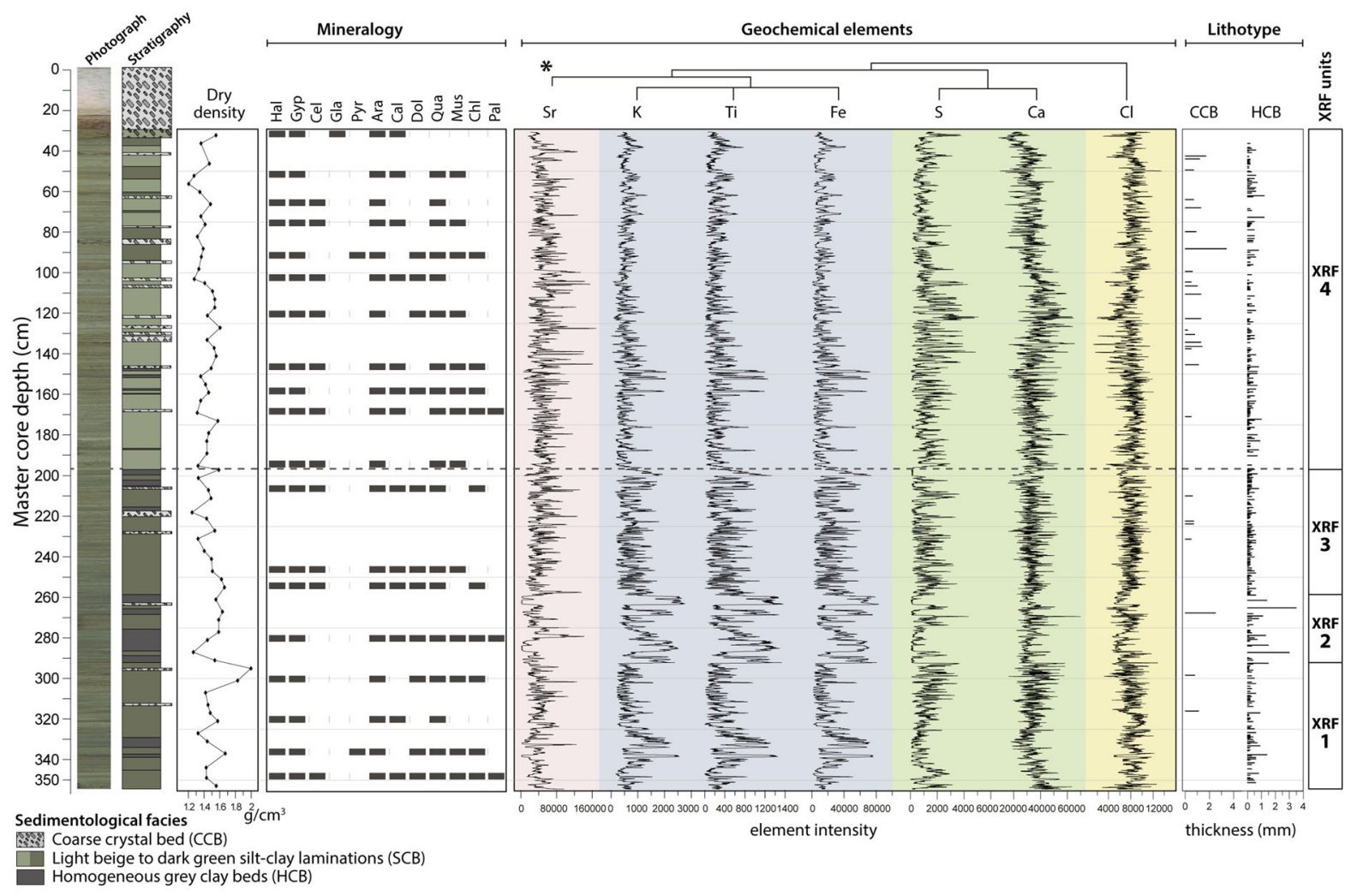

Fig. 3 Lithostratigraphy, mineralogy, dry bulk density, XRF elemental profiles, and lithofacies deposition in core MAH-B. Mineralogical species are abbreviated: Hal Halite, Gyp Gypsum, Cel Celestine, Gla Glauberite, Pyr Pyrite, Ara Aragonite,

organic particles, charcoals, and quartz. HCBs are represented in light grey in X-radiograph images.

The occurrence of the three lithofacies is repetitive down core. Most of the $26 \mathrm{CCBs}$ (excluding the modern one) were deposited between $145 \mathrm{~cm}$ and the core top. CCB thickness ranges between 0.2 and $35.7 \mathrm{~cm}$, with an average of $1.0 \mathrm{~cm}$. L-SCB (224 beds) and D-SCB (196 beds) are relatively homogeneously distributed along the profile, with thicknesses ranging from 0.1 to $2.9 \mathrm{~cm}$ and average values of 0.42 and $0.48 \mathrm{~cm}$, respectively. The $385 \mathrm{HCB}$ have thicknesses ranging between 0.1 and $3.5 \mathrm{~cm}$ (mean $0.3 \mathrm{~cm}$ ). HCBs are thicker between 285 and $260 \mathrm{~cm}(>1 \mathrm{~cm})$.

Geochemical variations

Depth-constrained cluster analysis of the high-resolution XRF profiles revealed four geochemical groups: $\mathrm{K}-\mathrm{Ti}-\mathrm{Fe}, \mathrm{Sr}, \mathrm{Ca}-\mathrm{S}$, and $\mathrm{Cl}$. $\mathrm{K}-\mathrm{Ti}-\mathrm{Fe}$ are mostly
Cal Calcite, Dol Dolomite, Qua Quartz, Mus Muscovite, Chl Chlorite, Pal Palygorskite. Elements ( $\mathrm{Sr}, \mathrm{K}, \mathrm{Ti}, \mathrm{Fe}, \mathrm{S}, \mathrm{Ca}, \mathrm{Cl}$ ) are shown following their degree of similarity, given by cluster analysis (asterisk). (Color figure online)

associated with $\mathrm{Sr}$ and to a lesser extent with $\mathrm{Ca}$ and $\mathrm{S}$. $\mathrm{Cl}$ is an isolated unit (Fig. 3).

\section{The Cl group}

$\mathrm{Cl}$ intensity represents halite abundance in the bulk sediment. The larger $\mathrm{Cl}$ fluctuations correspond to $\mathrm{CCB}$, although isolated crystals of halite sometimes occur in lithofacies L-SCB and D-SCB (Fig. 4A-1 and $\mathrm{A}-2$ ). $\mathrm{Cl}$ intensities are minimum in $\mathrm{HCB}$ beds characterised by higher detrital minerogenic elements (Fe, Ti, K).

\section{The group $\mathrm{Ca}, \mathrm{S}$}

Ca can be associated with gypsum, aragonite, calcite, and dolomite, whereas S may originate from gypsum, pyrite, and celestine. Both elements, however, are more concentrated in light SCBs (Fig. 4a) that consist mainly of gypsum and aragonite. Low correlation 
Table 2 Sedimentological and geochemical composition of the MAH-B lithofacies

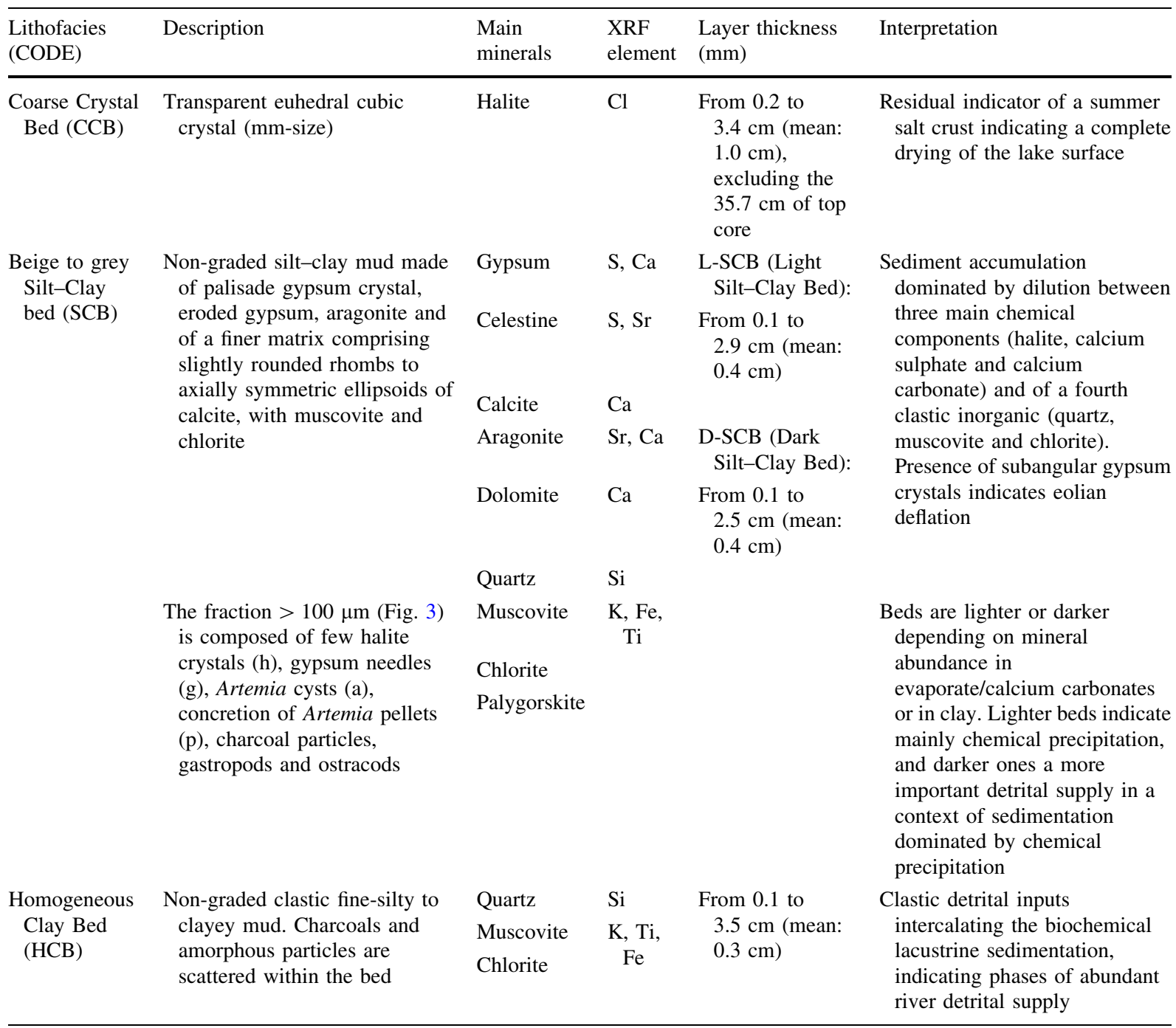

between $\mathrm{S}$ and $\mathrm{Fe}$, the rare occurrence of pyrite in the entire sediment sequence (Fig. 3), and the low S intensities in the samples where pyrite was detected by $\mathrm{XRD}$, indicate that $\mathrm{S}$ does not track pyrite. Poor correlation between $\mathrm{S}$ and $\mathrm{Sr}$ concentrations, along with the rare presence of celestine (Fig. 4a), also argues that $\mathrm{S}$ does not track celestine. The positive linear relationship between $\mathrm{S}$ and Ca likely reflects the dominance of gypsum in controlling the $S$ concentration, but the modest correlation coefficient $(r=0.5$; $\mathrm{n}=6360$ ) suggests that Ca values are also affected by other Ca-rich minerals (calcite, aragonite, and dolomite). Comparison between the ratio $\mathrm{Ca} / \mathrm{S}$ (data not shown) and detrital elements presents a moderate positive correlation (e.g. with $\mathrm{K}, \mathrm{r}=0.33$ ). This relationship suggests that some of the $\mathrm{Ca}$ may have a detrital origin. This supposition is supported by the presence of Mesozoic/Cenozoic carbonate rocks in the watershed and the presence of these minerals in riverbed sediments. Together, these results show that $\mathrm{Ca}$ probably has multiple mineral associations and origins (i.e. endogenic and allochthonous), whereas $\mathrm{S}$ is more securely driven by gypsum abundance only. As gypsum minerals occur mainly as palisade crystals, the main process of gypsum deposition in the lake sediment is as in situ, perpendicular growth relative to 

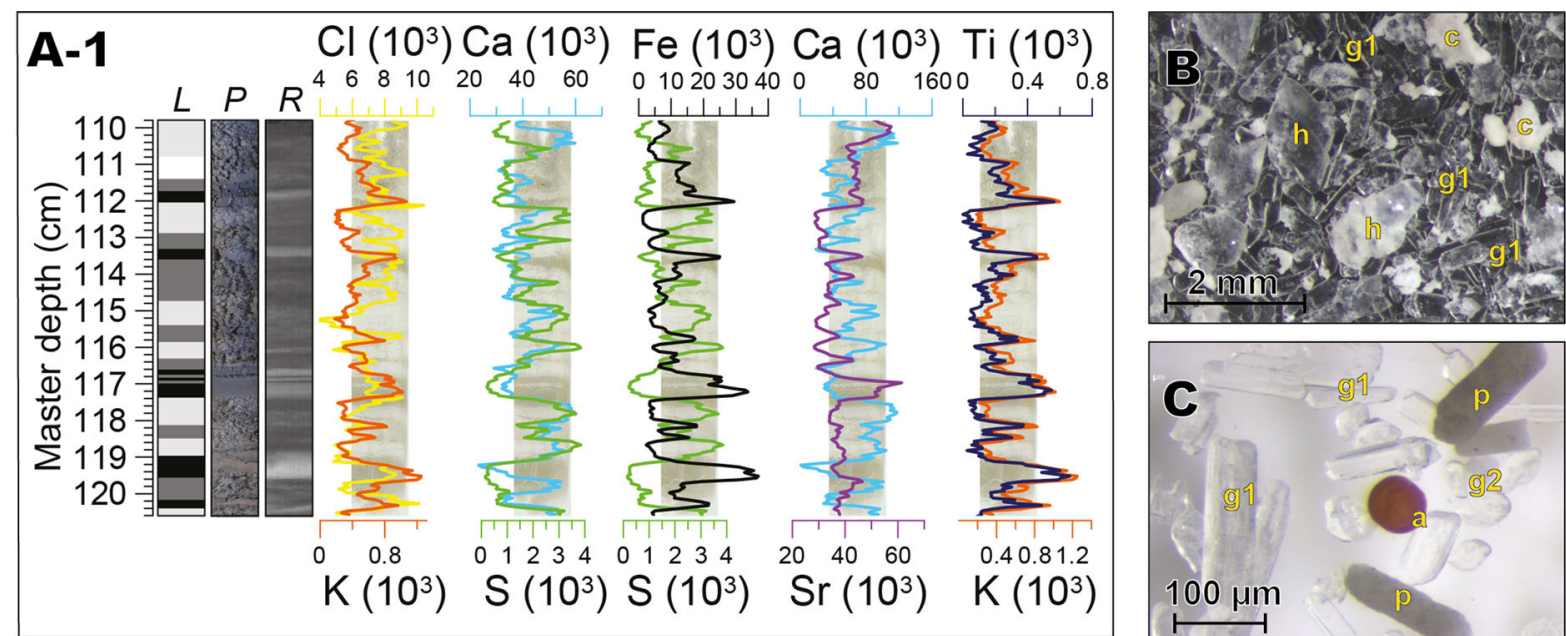

A-2 $\mathrm{Cl}\left(10^{3}\right) \mathrm{Ca}\left(10^{3}\right) \mathrm{Fe}\left(10^{3}\right) \mathrm{Ca}\left(10^{3}\right) \mathrm{Ti}\left(10^{3}\right)$
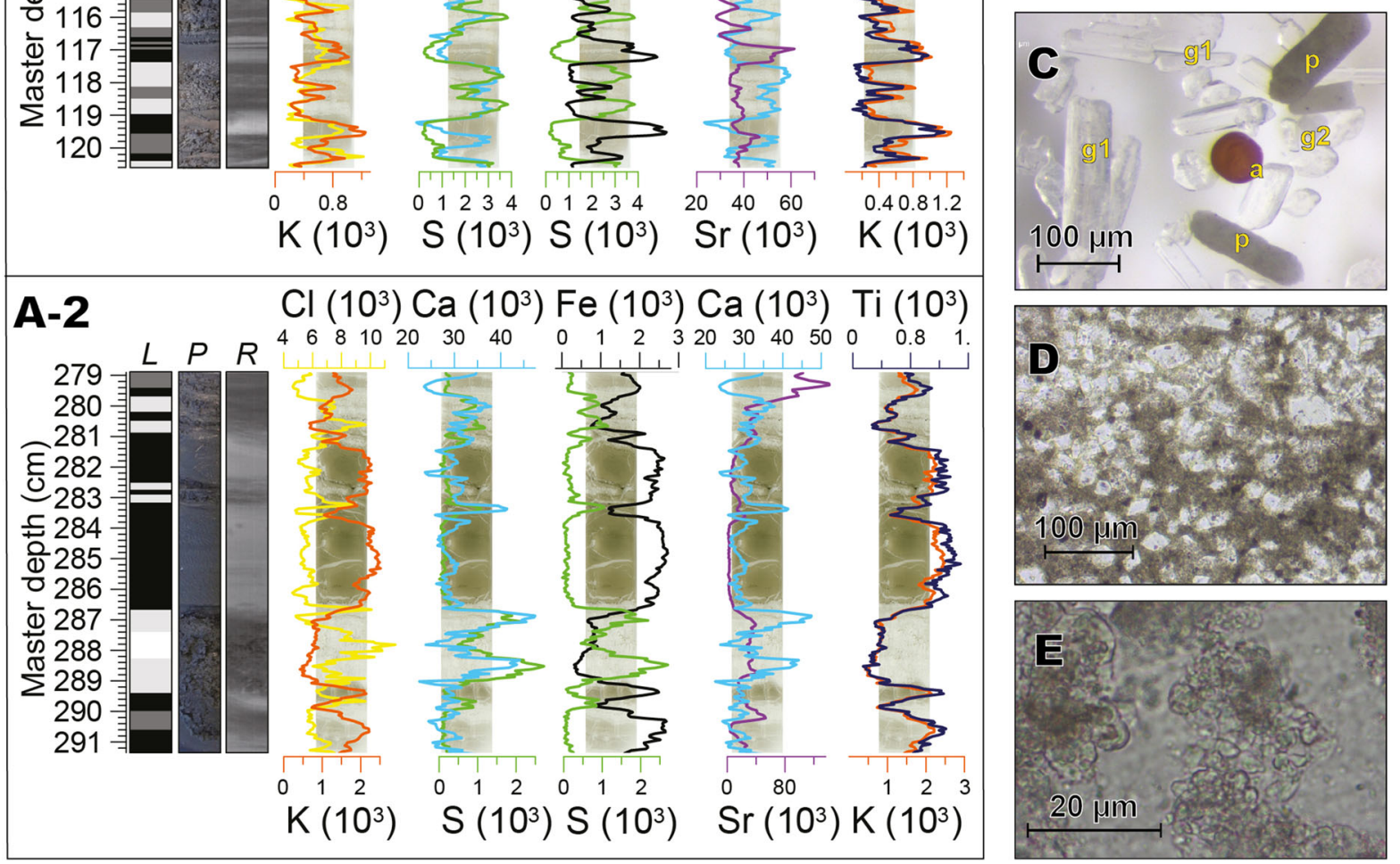

Fig. 4 a Macro- and microscopic characterisation of the lithofacies from two sediment segments corresponding to two thin sections A-1 $(110-120 \mathrm{~cm})$ and A-2 $(279-291 \mathrm{~cm})$. Lithofacies $(L)$ distinction (white: Coarse Crystal Beds (CCB); light grey: Light Silt-Clay Beds (L-SCB); dark grey: Dark SiltClay Beds (D-SCB); and black: Homogeneous Clay Beds $(\mathrm{HCB}))$, photographic image $(P)$, radiographic scan image $(R)$, and superposed thin-slide optical scans and high-resolution

the sedimentation surface, in a hypersaline pool. In lesser abundance, abraded gypsum crystals suggest allochthonous processes that may be associated with mechanical erosion from evaporitic outcrops or reworking by wind on the exposed dry lake surface. Absence of gypsum in riverbed sediments, together with the lack of a relationship between $S$ and detrital element $(\mathrm{K}, \mathrm{Fe}, \mathrm{Ti})$, refutes the hypothesis of supply by rivers. curves of the XRF intensities of $\mathrm{Cl}, \mathrm{K}, \mathrm{Ca}, \mathrm{Fe}, \mathrm{S}$ and $\mathrm{Ti}$ (corresponding scale to curve is shown by colour). $\mathbf{b}, \mathbf{c}>100$ $\mu \mathrm{m}$ sieved fraction made of: (h) halite, (g1) palisade gypsum crystal, (g2) subangular gypsum crystal, (c) calcium carbonate, (a) diapause cysts of Artemia and (p) Artemia aragonite pellets. d Euhedral gypsum crystals included in a calcite-clay matrix. e Ellipsoidal coalescent calcite particles

\section{The group $\mathrm{K}, \mathrm{Ti}, \mathrm{Fe}$}

Intensities of these elements are highest in HCBs and relatively high in D-SCBs. This group is associated with the presence of muscovite, chlorite and palygorskite minerals. Muscovite and chlorite are products of weathering of Mesozoic/Cenozoic rocks and are incorporated into the lake sediments as terrigenous, silt-clay-sized particles that are transported by fluvial or eolian processes. Although origin of palygorskite mineral may be detrital or endogenic, its occurrence in 
Lake Maharlou is associated only with the HCB lithofacies, suggesting a strictly detrital origin. Moreover, if the Si XRF signal is low (data not shown), Si shows the same variability as $\mathrm{K}, \mathrm{Ti}$, and $\mathrm{Fe}$, indicating the concordance of quartz together with phyllosilicates in HCB. Rare presence of diatoms confirms this interpretation. Two alternative interpretations can be proposed for the detrital element group. K, Ti, Fe may mostly track phyllosilicates that are deposited from turbid river discharge during heavy rainfall and thus be related to relatively high lake level, or phyllosilicates may be of eolian origin signalling arid conditions and thus be related to lake desiccation.

\section{The Sr group}

Peaks of Sr intensities are generally, but not exclusively, associated with L-SCBs and D-SCBs. Higher $\mathrm{Sr}$ intensities occur at depths where no celestine was recorded (e.g. 280-340 cm). Besides, $\mathrm{Sr}$ is often used to track Sr-rich aragonite (Böning and Bard 2009) that possibly reflects the abundance of aragonite-rich fecal pellets of the brine shrimp, Artemia (Fig. 4c). The lack of correlation between $\mathrm{Ca}$ and $\mathrm{Sr}$, however, cannot confirm this hypothesis. Dominance of gypsum likely overrides the less abundant aragonite and complicates the $\mathrm{Ca} / \mathrm{Sr}$ relationship.

\section{Discussion}

Defining palaeoenvironmental proxies

\section{Halite and gypsum as indicators of lake desiccation}

The sedimentological and geochemical analyses of MAH-B revealed a large range of biochemical and evaporitic products that are characteristic of different stages of concentration of the water (brine), related to retraction of the lake. Along the gradient of brine ionic concentration, low-solubility minerals such as calcite, aragonite and dolomite, are precipitated first, followed by gypsum, and finally halite (Hardie and Eugster 1970). Based on the analysis of the ion concentration of Lake Maharlou brine in summer 2002 and spring 2005, Fayazi et al. (2007) showed that during the driest conditions the salt crust comprises only halite, whereas under wetter conditions, several evaporite minerals, including mainly halite, gypsum, and calcium, are precipitated. In MAH-B, gypsum is mainly present in the form of elongated prismatic crystals and occurs in SCBs in association with carbonates and scattered halite grains. Gypsum formation requires a pool of water for the growth habit of the crystals.

In addition to variations in brine concentrations, other environmental factors can affect which minerals are deposited in a lake. Heterogeneities of basin morphology and proximity to freshwater inputs induce spatial variability with respect to the saturation point of different minerals (Bowler 1986), which are reached at different stages of water body contraction, depending on the location of the coring site (Rahimpour-Bonab and Abdi 2012). Distribution of cation concentrations in surface waters of Lake Maharlou indicates that the southeast of the lake has higher concentrations of $\mathrm{Na}^{+}$and $\mathrm{Cl}^{-}$(Fayazi et al. 2007) than the northeast deep basin, which is fed by the main tributaries. The MAH-B core site was located in the latter deep basin, but relatively close to the lake margin (Fig. 1). This location is more prone to surface crust formation than the deepest part of the lake, but less so than the shallower southern plateau. Thus, MAH-B is sensitive to an intermediate stage of water body contraction, corresponding to half the maximum current lake surface. Post-depositional mineral dissolution caused by cyclic flooding-desiccation also affects the integrity of hydrologic reconstruction (Last and Schweyen 1983). Dissolution is a differential process, first affecting the most soluble salts. Thus, despite the fact that gypsum can represent the complete record of changes in lake sedimentation, more soluble halite layers probably underestimate the number and intensity of past extreme desiccation events. Thus, gypsum abundance, tracked by S XRF intensity, is interpreted as an indicator of hypersaline conditions in Lake Maharlou, with some water still present. The frequency of indurated halite beds (CCB lithofacies) is interpreted as the residue of summer salt crusts, which indicate desiccation of more than $50 \%$ of the lake surface, thus corresponding to very low lake levels $(<1 \mathrm{~m})$ even in the deepest part of the lake.

\section{Detrital fraction as an indicator of river activity}

Detrital minerals (phyllosilicates and quartz) have been identified in HCB and D-SCB lithofacies and characterised by high XRF intensities of $\mathrm{K}, \mathrm{Ti}$, and $\mathrm{Fe}$. 
These minerals have two possible origins, eolian or alluvial. Dust storms that carry high sediment loads originate from two main atmospheric patterns. Shamal summer winds, oriented northwest-southeast, come from the Mediterranean and produce large dust deposits along the Euphrates Valley to the Persian Gulf. Frontal winds, coming from Saudi Arabia, generate dust storms in the northern part of the Zagros to the Caspian Sea (Nabavi et al. 2016). A retrospective atmospheric analysis, covering the period 1980 to Present (Nabavi et al. 2016), indicated that the Lake Maharlou Basin has not received substantial dust transport, in part because of the protected position of the basin with respect to the dominant summer winds (Rezazadeh et al. 2013). The same situation was observed for a major dust storm in July 2009, which did not trigger dust deposition in the study region (Hamidi et al. 2014). In addition, mineralogical and elemental studies of dust deposited in sediment traps in the Persian Gulf, along the Iranian coast, indicated the dust was dominated by calcite $(60 \%)$ and quartz (15\%) minerals (Ahmady-Birgani et al. 2015), with grain sizes of silt and clay. In Lake Maharlou sediments, although the grain size of dust is similar to the HCBs particles, these beds have low to no calcite content and are depleted in Ca (Fig. 4a). It is thus unlikely that detrital-rich HCBs correspond to dust-storm deposits. In contrast, the hypothesis of terrigenous input from rivers is supported by the occurrence of intense floods along the Khoshk River in the last few decades, which caused economic losses in the city of Shiraz (e.g. in December 1986 and February 1998) (Kowsar et al. 2009; Mardaneh and Keshtkar 2013; Jamali et al. 2015). Historical archives also mention major floods that devastated the town in $\mathrm{AD}$ 1630 and 1668. The hydrograph of the Khoshk River system indicates discharges of 200 and $350 \mathrm{~m}^{3} / \mathrm{s}$ with return periods of 25 and 100 years, respectively (Rivaz and Musavi-Jahromi 2012). Considering these two possible origins of the detrital material, i.e. dust storms and river supply, the latter is more likely to cause HCB layers and increases in K intensities.

HCB lithofacies are characterised by absence of graded microfabrics, suggesting that detrital sediment supply entered the lake and that the kinetics of deposition results from uniform suspension in the water column (Siegenthaler and Sturm 1991). The absence of internal, microscopic, graded bedding may also result from deposition distal from the river mouth
(Czymzik et al. 2013). MAH-B is located in the same northern basin as the river delta and in the path of the entering flow. The mouth of Khoshk River forms a vast $\left(8.5-\mathrm{km}\right.$-wide), relatively flat $\left(3^{\circ}\right.$ slope), fluviolacustrine delta that encompasses the entire width of the lake. This complex deltaic environment consists of numerous wetlands in which divergent streams, both intermittent and perennial, flow. Taking into account the low potential velocity and relatively low stream discharge, two explanations for the absence of coarse detrital particles in MAH-B are (i) quasi-permanent presence of dense aquatic vegetation (Juncus, Phragmites) in wetlands developed in the Khoshk River Delta environment, which buffer and trap the coarse sediment fraction, and (ii) sediment supply feeding the lake system and the coring site consists of turbid waters, with only clays/silts in suspension.

Climate: a forcing mechanism for hydrologic changes in Lake Maharlou?

3800 to 2000 cal year BP (period A): enhanced detrital supply during wetter climate conditions

The base of MAH-B, from 3800 to 2000 cal year BP, records peak abundance of terrigenous sediment (high $\mathrm{K}$ intensities, Fig. 5). High fluvial activity during this period corresponded with relatively low evaporative concentration of the lake. Rare phases of lake contraction (inferred from $\mathrm{S}$ intensities and $\mathrm{CCB}$ frequency, Fig. 5), however, did occur at 3700-3650, 3500-3450, and 3400-3250 cal year BP. Thus, this period is interpreted as having an overall positive hydrological balance, corresponding to higher river flow and lower water loss through evaporation. Superimposed on these general conditions are three $\mathrm{K}$ peaks and a peak in HCB frequency from 3800 to 3250 cal year BP. Enhanced detrital supply could be caused by rapid snow melt or large spring rains (Masih et al. 2011), possibly related to a highly unstable climate. Alternatively, it could be caused by the river adjusting course, moving its mouth closer to the coring location. From 3250 to 2000 cal year BP, flood frequency and $\mathrm{K}$ intensities decreased, suggesting more stable hydrological conditions and fewer pulses of fluvial sediment.

Higher river discharge in the Maharlou catchment fits well with other records that show a period of river alluviation in the Pulvar (Rigot 2010) and Kor (Kehl 
Fig. 5 Palaeohydrology reconstructed from Lake Maharlou proxies compared to records in southwest Asia, as a function of age (cal year BP). a Qunf Cave, southern Oman (Fleitmann et al. 2003, 2007). b Socotra Cave, Yemen (Van

Rampelbergh et al. 2013); Hoti Cave, northern Oman (Fleitmann et al. 2007). c Level of the Caspian Sea (Rychagov 1997;

Kroonenberg et al. 2007). d Lake Zeribar (Stevens et al. 2001; Snyder et al. 2001). e Lake Mirabad (Stevens et al. 2006). f Lake Parishan, Iran (Jones et al. 2015). g Historical cultural periods in the Fars region (Iran) and attention paid to repair and construction of new qanats. $\mathbf{h}$ Historical archives citing drought or famine in Iran (Frye 1984; Melville 1984; Daryaee 2014). i Geomorphic record of the Pulvar fluvial valley of the Persepolis basin, Iran (Rigot 2010). j Geomorphic record of the Central Iranian Plateau (Schmidt et al. 2011). k Geomorphic record of the Wadi ad Dawasir in central Saudi Arabia (Matter et al. 2016). 1 Inter-dune lake Awafi (Parker et al. 2006) and Idhn in United Arab Emirates (Goudie et al. 2000). m northern Arabian Sea offshore marine record (Lückge et al. 2001)

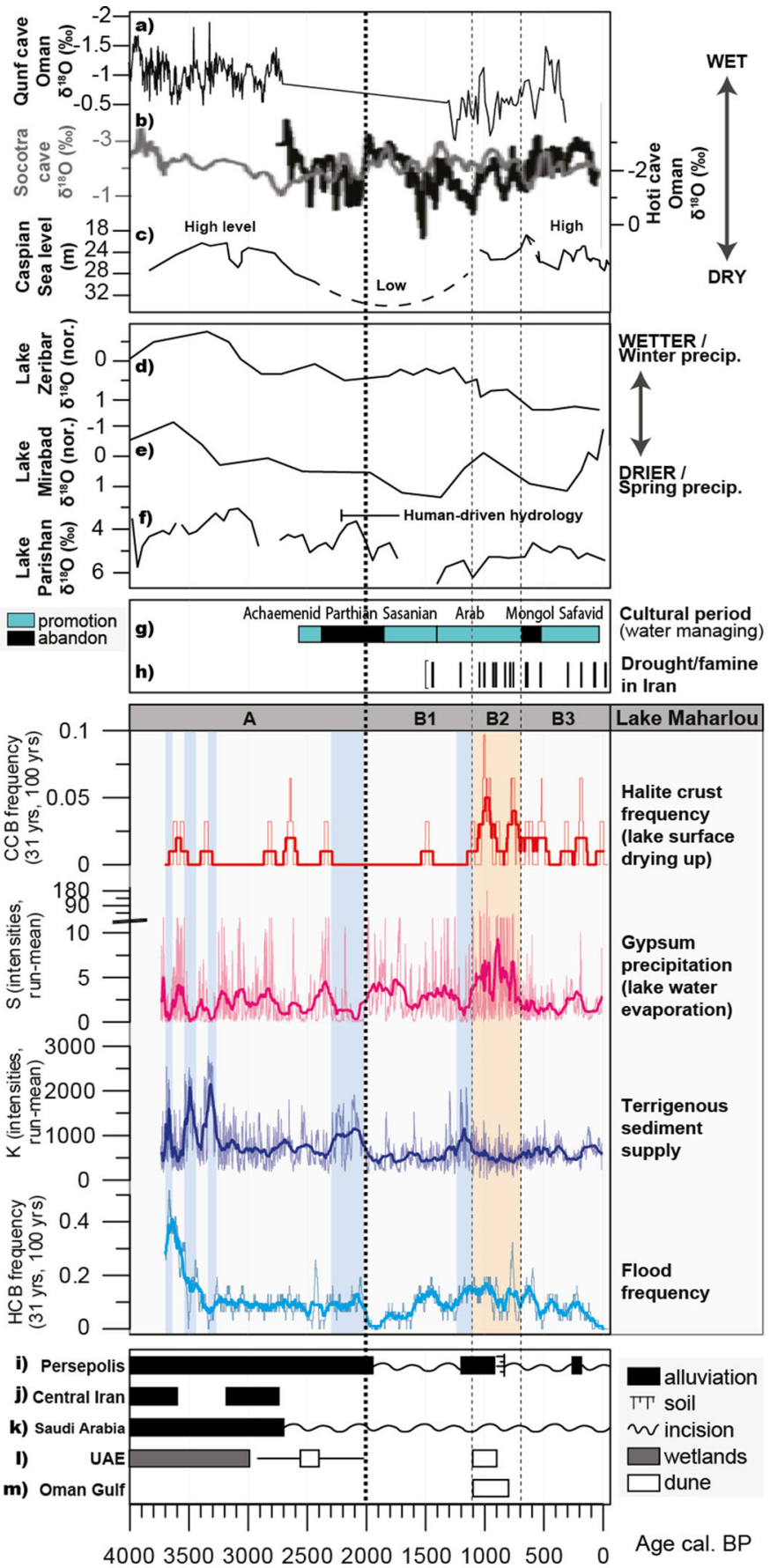

Location map of the proxy records (letters a to $m$ ), and of the Lake Maharlou (star):

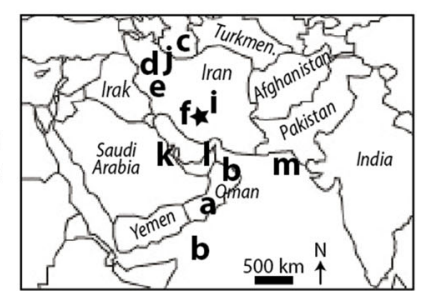


et al. 2009) River Valleys, which are located $50 \mathrm{~km}$ north of Lake Maharlou in the Persepolis Basin (Fig. 5i), alluviation in the northern part of the Iranian Plateau (Schmidt et al. 2011, Fig. 5j) and in the Arabian Peninsula (Matter et al. 2016, Fig. 5k). River terrace formation probably indicates that sediment was available on slopes and that water discharge was sufficient to transport those sediments. More humid conditions, which would be associated with stable river input, also explain the reduction in evaporative concentration of the lake surface. A generally wetter climate with pulsed river activity is consistent with the presence of inter-dune wetlands that indicate short-lived wet phases in the Arabian Peninsula (Parker et al. 2006, Fig. 51) and in a marine record from the Gulf of Oman (Lückge et al. 2001, Fig. $5 \mathrm{~m}$ ). The interpretation of wetter conditions in Southwest Asia from 3800 to 2000 cal year BP is also consistent with proxies that are more sensitive to effective moisture (Fig. 5a, b, c) than are geomorphic records. Lower values of the $\delta^{18} \mathrm{O}$ of speleothems from Qunf Cave in Oman (Fleitmann et al. 2003, 2007, Fig. 5a) and in Gejkar Cave in Iraq (Flohr et al. 2017), and higher levels of the Caspian Sea (Rychagov 1997, Fig. 5c), all argue for a regional increase in moisture. In the Iranian Plateau, higher lake levels from 3700 to 1900 cal year BP are documented by dominance of aquatic plants in the pollen diagram from Lake Almalou, with a peak high stand between 3700 and 3400 cal year BP (Djamali et al. 2009a). In Lake Parishan, some $100 \mathrm{~km}$ to the west of Lake Maharlou, both geochemical and paleoecological proxies suggest that between 3800 and 2200 cal year BP the lake was higher than periods before and after this interval (Jones et al. 2015).

\section{0 to Present (period B): increasing aridification and more lake low stands}

The main change in the catchment/lake hydrology occurred at ca. 2000 cal year BP, with an increase in gypsum abundance attesting to more evaporative conditions in the lake and decreased terrigenous input (Fig. 5). The timing of the transition is consistent with a major environmental change recorded in geomorphic records from the Iranian Plateau and the Arabian Peninsula (Fig. 5i-1): increased river incision and dune development at that time suggest drier climatic conditions. More arid conditions in this region are in phase with a lower Caspian Sea level (Rychagov 1997) and more positive $\delta^{18} \mathrm{O}$ values from the Qunf Cave (Fleitmann et al. 2003). A transitory increase in the detrital supply in Lake Maharlou between 1300 and 1100 cal year BP is concomitant with increased alluvial sediment deposition in the Persepolis Basin (Fig. 5i) that may reflect a short phase of more humid conditions (Rigot 2010).

From 1100 to 700 cal year BP (period B2, Fig. 5), Lake Maharlou experienced maximum reduction of its water body and very frequent desiccation events, as revealed by high gypsum abundance and frequent deposition of halite beds (CCB frequency), respectively. Dune formation and dust events in the Arabian Peninsula (Goudie et al. 2000; Lückge et al. 2001) suggest that a more arid climate might be responsible for the extreme evaporation of Lake Maharlou. In the Persepolis Basin, soils developed on previously deposited terraces (Rigot 2010), also suggesting very low fluvial activity. Speleothem records from northern and southern Oman seem to also indicate several short periods of drought (Fleitmann et al. 2007). The most compelling argument, however, is the frequency of drought and famine recorded in historical archives from Iran during this interval (Daryaee 2014; Sharifi et al. 2015; Fig. 5h).

Lake Maharlou underwent few desiccation periods and was likely a perennial water body from $700 \mathrm{cal}$ year BP to Present (period B3, Fig. 5), as indicated by a decrease in halite crust formation and gypsum abundance. Detrital input, however, remained low. These conditions correspond to fewer droughts and famines in Iran (Daryaee 2014). Hoti and Qunf Cave (Fleitmann et al. 2003, 2007) display modest decreases in $\delta^{18} \mathrm{O}$ at that time, suggesting relatively wetter climatic conditions than in period B2. This interval corresponds roughly to the Little Ice Age (600-150 cal year BP), during which cooling associated with lower solar irradiance and higher frequency of stratospheric volcanic eruptions may have reduced evaporation stress (greater effective moisture), resulting in less halite crust formation at Lake Maharlou. Similar results are documented for Lake Almalou (Djamali et al. 2009a) and Caspian Sea level (Naderi Beni et al. 2014). Contrasting dynamics, however, have been documented at other sites, suggesting a decrease in effective moisture (Jones et al. 2006; Flohr et al. 2017) that may have induced lower lake level. Finally, coherence between many proxy records from 
the Mediterranean and Southwest Asia, with respect to a general drying trend from the middle to late Holocene, may be explained by a weakening of the winter storm tracks that originate from the Mediterranean and North Atlantic, even if regional-scale experiments suggest a much more complex circulation pattern (Brayshaw et al. 2011) caused by the orography in this region (Zarrin et al. 2011).

Equivocal palaeohydrological interpretations of lake records in the Zagros Massif: how strong was the influence of humans?

Comparisons with geomorphic and speleothem archives suggest that hydrological changes at Lake Maharlou were driven by late Holocene climatic changes that were manifest over much of southwest Asia. Comparison of the record presented here with those from three other lakes in the Zagros Massif [Lake Zeribar (Fig. 5d), Lake Mirabad (Fig. 5e) and Lake Parishan (Fig. 5f)], however, reveals complexities. During the last 4000 years, the lowest $\delta^{18} \mathrm{O}$ values measured on endogenic calcite at Mirabad and Zeribar occurred during periods of high terrigenous supply at Lake Maharlou (Fig. 5). Then at $2000 \mathrm{cal}$ year BP, increasing $\delta^{18} \mathrm{O}$ values corresponded to an increase of gypsum abundance in Lake Maharlou. These general trends suggest a common forcing factor affected lake-water balances of the Zagros region. It has been proposed, however, that $\delta^{18} \mathrm{O}$ values are not controlled entirely by hydrologic balance (Jones and Roberts 2008), and that the seasonality of precipitation should be considered (Snyder et al. 2001; Stevens et al. 2001, 2006). In Lake Parishan, Jones et al. (2015) did not find any common climatic explanation for the increase of the $\delta^{18} \mathrm{O}$ with changes in ostracod assemblages, and variations of other geochemical and biological indicators occurring at 2000 cal year BP. These authors invoked large-scale anthropogenic disturbances of the water cycle in the watershed to explain variations in the lake hydro-geochemistry.

With respect to Lake Maharlou, anthropogenic activities caused or simply amplified the decrease in both fluvial activity and lake volume. Notably, the $\mathrm{HCB}$ frequency and $\mathrm{K}$ intensities diverge after 2000 cal year BP, suggesting a modification of the relationship between the flood frequency and the sediment supply. This pattern could be explained by ecological and geomorphic factors in the face of climate variability, possibly influenced by anthropogenic activities (Brisset et al. 2017). For example, lower detrital supply with relatively frequent flood events may suggest that the erosive effect of precipitation and runoff was buffered by vegetation cover in the lake catchment, a change in the ratio of discharge to sediment load (Brisset et al. 2014), development of riparian vegetation along the river banks and the delta, or by sediment mining for urban development (Rinaldi et al. 2005).

A 4800-year pollen diagram from another core taken in Lake Maharlou (Djamali et al. 2009b, 2010a, b) shows that vegetation cover was generally dominated by Quercus and Pistacia, scrub species typical of the Zagros Mountains. A marked increase in Juglans, Platanus, and Olea in that core, however, attests to intensification of cultivation practices and urban development, both of which were favoured by advances in irrigation techniques. Temporal comparisons with this core are not possible because radiocarbon ages were obtained on bulk carbonate (Djamali et al. 2009b) and variable reservoir effect prevents reconciliation with dates on macrofossils. Effective management of water resources has been a common way to cope with arid conditions in Southwest Asia (Magee 2005). Archaeological findings indicate that subterranean tunnels (i.e. qanat or kariz systems) were used to drain groundwater from foothills to irrigate plains since the 1st and possibly 2nd millennium BCE (Al Tikriti 2002; Magee 2005; Fattahi 2015). Because of the strong concentration of precipitation in winter/spring seasons throughout most of the Iranian Plateau, the introduction of qanat technology provided access to perennial water sources, modifying people's ability to subsist within this region (Manuel et al. 2017). Estimates of the number of functioning qanats in Iran range from 22,000 to 36,000 (Semsar Yazdi and Askarzadeh 2007). The length of some qanats may extend over several hundred $\mathrm{km}$, with most ranging from 5 to $10 \mathrm{~km}$ (Wilkinson et al. 2012). The qanat irrigation network located in the watershed of Lake Maharlou is very dense (Fig. 1b). Even if a large number of those qanats are currently abandoned, their high abundance argues for strong disturbances in the drainage basin of the lake through changes in groundwater input to the lake, which in turn would accelerate lake drying. The importance given to the management of the water supply has not been the same throughout the different 
empires that ruled in Persia ('Persis') (Fig. 5g). According to Manuel et al. (2017), little attention was paid to water system sustainability during the Seleucid and Parthian Empires (2197-1726 cal year $\mathrm{BP}$ ), whereas during the reign of the Sasanians (1726-1300 cal year BP), the state supported the development and maintenance of qanats, but also surface water networks. Thus, the turning points in Lake Maharlou hydrology coincide with these imperial periods: the first major reduction of the water body (gypsum abundance, period B1 in Fig. 5) occurred at 2160-1980 cal year BP $(2 \sigma)$. Then, the period of more frequent, nearly complete drying of the lake (CCB bed frequency, period B2 in Fig. 5), occurred during the Islamic period, while qanats were still utilised (Manuel et al. 2017). The long-term utilisation of the water resources, over millennia, may thus have been an important factor in Lake Maharlou drying during the past, similar to the situation at neighbouring Lake Parishan (Jones et al. 2015).

Finally, temporal synchronicity of climate proxies and intensity of human activities suggest that both climate and human drivers influenced Lake Maharlou hydrological changes over the last four millennia. Even if it remains difficult to decipher the relative role of each forcing factor on the lake's evolution, a probable and parsimonious interpretation might be that large-scale climate changes may have induced a water deficit that was further aggravated by alteration of the water cycle by anthropogenic activities. Thus, in the face of the global change and an increasing need for fresh water for agriculture and urban use, particular attention should be given to sustainable water resource management. Historical instrumental records, combined with secular to millennial-scale records of hydrological changes, provide helpful information to understand the function of water resources.

\section{Conclusions}

Analyses carried out on core MAH-B from Lake Maharlou reveal four past hydro-environmental states: (1) near or total desiccation of the lake (frequency of halite beds), (2) an intermediate phase of lake water body retraction (gypsum abundance), (3) high terrigenous sediment supply from rivers (potassium abundance), and (4) river flood occurrence (frequency of the individual beds of homogeneous clays). Of these four states, two major periods were identified over the last 3800 years. From 3800 to 2000 cal year BP, the terrigenous supply was high (notably in the intervals 3700-3650, 3500-3450, and 3400-3250 cal year BP), and evaporative conditions of the lake surface were relatively low. From 2000 cal year BP to Present, an increase in gypsum attests to more evaporative conditions, concomitant with a decrease in fluvial activity. The contraction of the water body reached a maximum from 1100 to $700 \mathrm{cal}$ year BP, during which the lake frequently dried.

The comparison of the Lake Maharlou records to geomorphic activity and to climatically driven regional records suggests that a common climate forcing controlled late Holocene hydrology in southwest Asia. Comparison with the lake records located in the Zagros Massif is more challenging because these records yielded equivocal conclusions about hydrological changes inferred from different climate proxies. Indeed, ancient human impact on local and regional hydrologic balance is likely to have impacted lake systems for millennia. Subterranean tunnels (qanats) are an important component of the Maharlou watershed. Periods of construction of new qanats and repair (Sassanid and Islamic periods) seem to have corresponded to the dramatic contraction of the water body, suggesting that human disturbances of the water cycle in the lake watershed played a role in the lake water deficit, along with climate change. As both periods of climatic change and human impact correspond to hydrological variability of Lake Maharlou, we suggest that weaker winter storm tracks originating from the Mediterranean may have induced water shortage that was aggravated by human activity, leading to more frequent drying of Lake Maharlou. In turn, scarcity of the water resource has had a severe impact on food security, as famines have coincided with exceptionally frequent lake drying during the last millennium.

Acknowledgements This study was funded by the FrancoGerman ANR/DGF titled PALEO-PERSEPOLIS (ANR-14CE35-0026-01). The authors thank M. Köhler (MK Factory) for thin-section preparation and T. Goslar (Poznan Radiocarbon Laboratory) for ${ }^{14} \mathrm{C}$ measurements and related details on sample preparation and blank correction. A. Naderi-Beni and $\mathrm{M}$. Pourkerman from the Iranian National Institute for Oceanography and Atmospheric Sciences are thanked for their help with the coring operation. We are grateful to the reviewers and M. Brenner (Editor in Chief of JOPL) for their salient suggestions for improvement of the manuscript. 


\section{References}

Abarghouei HB, Zarch MAA, Dastorani MT, Kousari MR, Zarch MS (2011) The survey of climatic drought trend in Iran. Stoch Environ Res Risk Assess 25:851

Abbaspour KC, Faramarzi M, Ghasemi SS, Yang H (2009) Assessing the impact of climate change on water resources in Iran. Water Resour Res 45:W10434

Ahmady-Birgani H, Mirnejad H, Feiznia S, McQueen KG (2015) Mineralogy and geochemistry of atmospheric particulates in western Iran. Atmos Environ 119:262-272

Al Tikriti WY (2002) The south-east Arabian origin of the falaj system. Proc Sem Arab Stud 32:117-138

Alijani B, Harman JR (1985) Synoptic climatology of precipitation in Iran. Ann Assoc Am Geogr 75:404-416

Aubert C, Brisset E, Djamali M, Sharifi A, Ponel P, Gambin B, Azirani TA, Guibal F, Lahijani H, Beni AN, de Beaulieu J-L, Pourmand A, Andrieu-Ponel V, Thiéry A, Gandouin E (2017) Late glacial and early Holocene hydroclimate variability in northwest Iran (Talesh Mountains) inferred from chironomid and pollen analysis. J Paleolimnol 58:151-167

Bennett KD (1996) Determination of the number of zones in a biostratigraphical sequence. New Phytol 132:155-170

Blaauw M (2010) Methods and code for "classical" age-modelling of radiocarbon sequences. Quat Geochronol 5:512-518

Böning P, Bard E (2009) Millennial/centennial-scale thermocline ventilation changes in the Indian Ocean as reflected by aragonite preservation and geochemical variations in Arabian Sea sediments. Geochim Cosmochim Acta 73:6771-6788

Bowler JM (1986) Spatial variability and hydrologic evolution of Australian lake basins: analogue for pleistocene hydrologic change and evaporite formation. Palaeogeogr Palaeoclimatol Palaeoecol 54:21-41

Brauer A, Casanova J (2001) Chronology and depositional processes of the laminated sediment record from Lac d'Annecy, French Alps. J Paleolimnol 25:163-177

Brayshaw DJ, Black E, Hoskins B, Slingo J (2011) Past climates of the Middle East. In: Mithen S, Black E (eds) Water, life and civilisation: climate, environment and society in the Jordan Valley. International Hydrology Series. Cambridge University Press, Cambridge, pp 25-50

Brisset E, Miramont C, Anthony EJ, Bruneton H, Rosique T, Sivan O (2014) Sediment budget quantification of a subAlpine river catchment since the end of the last glaciation. CATENA 114:169-179

Brisset E, Guiter F, Miramont C, Troussier T, Sabatier P, Poher Y, Cartier R, Arnaud F, Malet E, Anthony EJ (2017) The overlooked human influence in historic and prehistoric floods in the European Alps. Geology 45:347-350

Coops H, Beklioglu M, Crisman TL (2003) The role of waterlevel fluctuations in shallow lake ecosystems-workshop conclusions. Hydrobiologia 506-509:23-27

Czymzik M, Brauer A, Dulski P, Plessen B, Naumann R, von Grafenstein U, Scheffler R (2013) Orbital and solar forcing of shifts in Mid- to Late Holocene flood intensity from varved sediments of pre-alpine Lake Ammersee (southern Germany). Quat Sci Rev 61:96-110
Daryaee T (2014) Sasanian Persia: the rise and fall of an empire. I. B. Tauris, London, p 311

Dearing JA (2013) Why Future Earth needs lake sediment studies. J Paleolimnol 49:537-545

Degen T, Sadki M, Bron E, König U, Nénert G (2014) The highscore suite. Powder Diffr 29:13-18

Djamali M, de Beaulieu J-L, Andrieu-Ponel V, Berberian M, Miller NF, Gandouin E, Lahijani H, Shah-Hosseini M, Ponel P, Salimian M, Guiter F (2009a) A late Holocene pollen record from Lake Almalou in NW Iran: evidence for changing land-use in relation to some historical events during the last 3700 years. J Archaeol Sci 36:1364-1375

Djamali M, de Beaulieu J-L, Miller NF, Andrieu-Ponel V, Ponel P, Lak R, Sadeddin N, Akhani H, Fazeli H (2009b) Vegetation history of the SE section of the Zagros Mountains during the last five millennia; a pollen record from the Maharlou Lake, Fars Province, Iran. Veget Hist Archaeobot 18:123-136

Djamali M, Ponel P, Andrieu-Ponel V, de Beaulieu J-L, Guibal F, Miller NF, Ramezani E, Berberian M, Lahijani H, Lak R (2010a) Notes on arboricultural and agricultural practices in ancient Iran based on new pollen evidence. Paléorient 36:175-188

Djamali M, Ponel P, Delille T, Thiéry A, Asem A, AndrieuPonel V, de Beaulieu J-L, Lahijani H, Shah-Hosseini M, Amini A (2010b) A 200,000-year record of the brine shrimp Artemia (Crustacea: Anostraca) remains in Lake Urmia, NW Iran. Int J Aquat Sci 1:14-18

Dumas D, Mietton M, Humbert J (2003) Le fonctionnement hydroclimatique de la cuvette de Maharlou (Iran). Sécheresse 14:1-8

Faghih A, Samani B, Kusky T, Khabazi S, Roshanak R (2012) Geomorphologic assessment of relative tectonic activity in the Maharlou Lake Basin, Zagros Mountains of Iran. Geol J 47:30-40

Fattahi M (2015) OSL dating of the Miam Qanat (Kāriz) system in NE Iran. J Archaeol Sci 59:54-63

Fayazi F, Lak R, Nakhaei M (2007) Hydrochemistry and brine evolution of Maharlou saline lake, Southwest of Iran. Carbonate Evaporite 22:33-42

Fleitmann D, Burns SJ, Mudelsee M, Neff U, Kramers J, Mangini A, Matter A (2003) Holocene forcing of the Indian Monsoon recorded in a stalagmite from Southern Oman. Science 300:1737-1739

Fleitmann D, Burns SJ, Mangini A, Mudelsee M, Kramers J, Villa I, Neff U, Al-Subbary AA, Buettner A, Hippler D, Matter A (2007) Holocene ITCZ and Indian monsoon dynamics recorded in stalagmites from Oman and Yemen (Socotra). Quat Sci Rev 26:170-188

Flohr P, Fleitmann D, Zorita E, Sadekov A, Cheng H, Bosomworth M, Edwards L, Matthews W, Matthews R (2017) Late Holocene droughts in the Fertile Crescent recorded in a speleothem from northern Iraq. Geophys Res Lett 44:2016GL071786

Frye RN (1984) The history of ancient Iran, vol 7. CH Beck edition, Munschen

Goudie AS, Colls A, Stokes S, Parker A, White K, Al-Farraj A (2000) Latest Pleistocene and Holocene dune construction at the north-eastern edge of the Rub Al Khali, United Arab Emirates. Sedimentology 47:1011-1021 
Hamidi M, Kavianpour MR, Shao Y (2014) Numerical simulation of dust events in the Middle East. Aeolian Res 13:59-70

Hardie LA, Eugster HP (1970) The evolution of closed-basin brines. Mineral Soc Am Spec Paper 3:270-290

Jamali M, Moghimi E, Jafarpour Z, Kardovani P (2015) Spatial analysis of geomorphological hazards of urban development in the Banks of Khoshk River in Shiraz, Iran. J Spat Anal Environ Hazards 2:51-61

Jones MD, Roberts CN (2008) Interpreting lake isotope records of Holocene environmental change in the Eastern Mediterranean. Quat Int 181:32-38

Jones MD, Roberts CN, Leng MJ, Türkeş M (2006) A highresolution late Holocene lake isotope record from Turkey and links to North Atlantic and monsoon climate. Geology 34:361-364

Jones MD, Djamali M, Holmes J, Weeks L, Leng MJ, Lashkari A, Alamdari K, Noorollahi D, Thomas L, Metcalfe SE (2015) Human impact on the hydroenvironment of Lake Parishan, SW Iran, through the late-Holocene. Holocene 25:1651-1661

Juggins S (2012) C2 v.1.5, User guide. Software for ecological and palaeoecological data analysis and visualisation. Newcastle University, Newcastle

Kehl M, Frechen M, Skowronek A (2009) Nature and age of Late Quaternary basin fill deposits in the Basin of Persepolis/Southern Iran. Lower Latitudes Loess-Dust Transport Past and Present. Quat Int 196:57-70

Kelts K, Shahrabi M (1986) Holocene sedimentology of hypersaline Lake Urmia, Northwestern Iran. Palaeogeogr Palaeoclimatol Palaeoecol 54:105-130

Kowsar A, Reza Khooban M, Hossein Borhan M (2009) Envelope curves for extreme flood events in SW Iran. In: Proceedings of 5th international conference on rain water cistern systems, Taiwan, pp 210-219

Kroonenberg SB, Abdurakhmanov GM, Badyukova EN, van der Borg K, Kalashnikov A, Kasimov NS, Rychagov GI, Svitoch AA, Vonhof HB, Wesselingh FP (2007) Solarforced $2600 \mathrm{BP}$ and Little Ice Age highstands of the Caspian Sea. Quat Int 173:137-143

Last WM, Schweyen TH (1983) Sedimentology and geochemistry of saline lakes of the Great Plains. Hydrobiologia 105:245-263

Lückge A, Doose-Rolinski H, Khan AA, Schulz H, von Rad U (2001) Monsoonal variability in the northeastern Arabian Sea during the past 5000 years: geochemical evidence from laminated sediments. Palaeogeogr Palaeoclimatol Palaeoecol 167:273-286

Magee P (2005) The chronology and environmental background of Iron Age settlement in Southeastern Iran and the question of the origin of the Qanat irrigation system. Iran Antiq 40:217-231

Manuel M, Lightfoot D, Fattahi M (2017) The sustainability of ancient water control techniques in Iran: an overview. Water Hist 10:1-18

Mardaneh M, Keshtkar S (2013) Groundwater flood risk "Khoshk" river in Shiraz. J Appl Environ Biol Sci 3:14-22

Masih I, Uhlenbrook S, Maskey S, Smakhtin V (2011) Streamflow trends and climate linkages in the Zagros Mountains, Iran. Clim Change 104:317-338
Matter A, Mahjoub A, Neubert E, Preusser F, Schwalb A, Szidat S, Wulf G (2016) Reactivation of the Pleistocene transArabian Wadi ad Dawasir fluvial system (Saudi Arabia) during the Holocene humid phase. Geomorphology 270:88-101

Melville C (1984) Meteorological hazards and disasters in Iran: a preliminary survey to 1950 . Iran 22:113-150

Motagh M, Walter TR, Sharifi MA, Fielding E, Schenk A, Anderssohn J, Zschau J (2008) Land subsidence in Iran caused by widespread water reservoir overexploitation. Geophys Res Lett 35:L16403

Nabavi SO, Haimberger L, Samimi C (2016) Climatology of dust distribution over West Asia from homogenized remote sensing data. Aeolian Res 21:93-107

Naderi Beni A, Lahijani H, Pourkerman M, Jokar R, Hosseindoust M, Marriner N, Djamali M, Andrieu-Ponel V, Kamkar A (2014) Caspian Sea-level changes at the end of Little Ice Age and its impacts on the avulsion of the Gorgan River: a multidisciplinary case study from the southeastern flank of the Caspian Sea. Méditerr 122:145-155

Neugebauer I, Schwab MJ, Waldmann ND, Tjallingii R, Frank U, Hadzhiivanova E, Naumann R, Taha N, Agnon A, Enzel Y, Brauer A (2016) Hydroclimatic variability in the Levant during the early last glacial ( 117-75 ka) derived from micro-facies analyses of deep Dead Sea sediments. Clim Past 12:75-90

Parker AG, Goudie AS, Stokes S, White K, Hodson MJ, Manning M, Kennet D (2006) A record of Holocene climate change from lake geochemical analyses in southeastern Arabia. Quat Res 66:465-476

Rahimpour-Bonab H, Abdi L (2012) Sedimentology and origin of Meyghan lake/playa deposits in Sanandaj-Sirjan zone, Iran. Carbonates Evaporites 27:375-393

Reimer PJ, Bard E, Bayliss A, Beck JW, Blackwell PG, Ramsey $\mathrm{CB}$, Buck CE, Cheng H, Edwards RL, Friedrich $\mathrm{M}$ et al (2013) IntCal13 and Marine13 radiocarbon age calibration curves 0-50,000 years cal BP. Radiocarbon 55:1869-1887

Rezaei A, Zare M, Raeisi E, Ghanbari RN (2013) Interaction of a fresh water lake and a karstic spring via a syncline fold. Groundwater 51:305-312

Rezazadeh M, Irannejad P, Shao Y (2013) Climatology of the Middle East dust events. Aeolian Res 10:103-109

Rigot JB (2010) Dynamique de la rivière Poulvar et morphogenèse de la plaine de Tang-i Bulaghi (Fars, Iran) à l'Holocène. Premiers résultats. Géomorphologie 16:57-72

Rinaldi M, Wyżga B, Surian N (2005) Sediment mining in alluvial channels: physical effects and management perspectives. River Res Appl 21:805-828

Rivaz N, Musavi-Jahromi SH (2012) Effect of bridges on the river hydrograph characteristics along the ephemeral rivers system. World Appl Sci J 19:248-256

Rychagov GI (1997) Holocene oscillations of the Caspian Sea, and forecasts based on palaeogeographical reconstructions. Quat Int 41:167-172

Salami H, Shahnooshi N, Thomson KJ (2009) The economic impacts of drought on the economy of Iran: an integration of linear programming and macroeconometric modelling approaches. Participation and Evaluation for Sustainable River Basin Governance. Ecol Econ 68:1032-1039

Schmidt A, Quigley M, Fattahi M, Azizi G, Maghsoudi M, Fazeli H (2011) Holocene settlement shifts and 
palaeoenvironments on the Central Iranian Plateau: investigating linked systems. Holocene 21:583-595

Semsar Yazdi AA, Askarzadeh S (2007) A historical review on the Qanats and historic hydraulic structures of Iran since the first millennium BC. In: International history seminar on irrigation and drainage, Tehran, $\mathrm{p} 12$

Sharifi A, Pourmand A, Canuel EA, Ferer-Tyler E, Peterson LC, Aichner B, Feakins SJ, Daryaee T, Djamali M, Beni AN, Lahijani HAK, Swart PK (2015) Abrupt climate variability since the last deglaciation based on a high-resolution, multi-proxy peat record from NW Iran: the hand that rocked the Cradle of Civilization? Quat Sci Rev 123:215-230

Siegenthaler C, Sturm M (1991) Slump induced surges and sediment transport in Lake Uri, Switzerland. Verh Internat Verein Limnol 24:955-958

Snyder JA, Wasylik K, Fritz SC, Wright HE (2001) Diatombased conductivity reconstruction and palaeoclimatic interpretation of a 40-ka record from Lake Zeribar, Iran. Holocene 11:737-745

Stevens LR, Wright HE, Ito E (2001) Proposed changes in seasonality of climate during the Lateglacial and Holocene at Lake Zeribar, Iran. Holocene 11:747-755

Stevens LR, Ito E, Schwalb A, Wright HE (2006) Timing of atmospheric precipitation in the Zagros Mountains inferred from a multi-proxy record from Lake Mirabad, Iran. Quat Res 66:494-500

Stevens LR, Djamali M, Andrieu-Ponel V, de Beaulieu J-L (2012) Hydroclimatic variations over the last two glacial/ interglacial cycles at Lake Urmia, Iran. J Paleolimnol 47:645-660

Tourian MJ, Elmi O, Chen Q, Devaraju B, Roohi S, Sneeuw N (2015) A spaceborne multisensor approach to monitor the desiccation of Lake Urmia in Iran. Remote Sens Environ 156:349-360

Tyrlis E, Lelieveld J, Steil B (2013) The summer circulation over the eastern Mediterranean and the Middle East: influence of the South Asian monsoon. Clim Dyn 40:1103-1123

Van Rampelbergh M, Fleitmann D, Verheyden S, Cheng H, Edwards L, De Geest P, De Vleeschouwer D, Burns SJ, Matter A, Claeys P, Keppens E (2013) Mid- to late Holocene Indian Ocean Monsoon variability recorded in four speleothems from Socotra Island, Yemen. Quat Sci Rev 65:129-142

Wilkinson TJ, Boucharlat R, Ertsen MW, Gillmore G, Kennet D, Magee P, Rezakhani K, Schacht TD (2012) From human niche construction to imperial power: long-term trends in ancient Iranian water systems. Water Hist 4:155-176

Wurtsbaugh WA, Miller C, Null SE, DeRose RJ, Wilcock P, Hahnenberger M, Howe F, Moore J (2017) Decline of the world's saline lakes. Nat Geosci 10:816-821

Zarrin A, Ghaemi H, Azadi M, Mofidi A, Mirzaei E (2011) The effect of the Zagros Mountains on the formation and maintenance of the Iran Anticyclone using RegCM4. Meteorol Atmos Phys 112:91-100 